\title{
Community Participation as an Aspect of Social Capital at Tourism Village
}

\author{
Purwanti Dyah Pramanik ${ }^{1}$, Rahmat Ingkadijaya ${ }^{2}$, and Mochamad Achmadi $^{3}$ \\ ${ }^{123}$ Sekolah Tinggi Pariwisata Trisakti, Jakarta, Indonesia
}

Email: ${ }^{1}$ Purwanti Dyah Pramanik@stptrisakti.ac.id, ${ }^{2}$ Rahmat Ingkadijaya@stptrisakti.ac.id, and ${ }^{3}$ achmadi@stptrisakti.ac.id

\begin{abstract}
The research aimed to identify community participation as an aspect of social capital in Kampung Tajur Tourism Village (KTTV), Purwakarta, West Java. The method used descriptive quantitative method. The study was cross sectional. Respondents were 38 families who lived in KTTV. Sampling was collected by convenience sampling. Variable in this research is participation as an aspect of social capital. The primary data was completed by distributing questionnaires to respondents. Questionnaire is divided into two parts. The first part is respondent's profiles and the second part is participation variable. Data processing includes: descriptive and correlation test. The study was conducted in October and December 2017. The results showed that the groups of female respondents who have jobs as farmers and housewives had a strong correlation and even tend to be very strong in shaping community participation. On the other hand, the age, the level of education, and income has no strong relation to build participation in KTTV.
\end{abstract}

\section{Keywords-Community Participation; Tourism Village; Social Capital.}

\section{INTRODUCTION}

The government is currently encouraging tourist visits intensively. Central Bureau of Statistics (BPS) published that the number of tourists to Indonesia in September 2017 reached 1,21 million . It means that it's grown $20,47 \%$ comparing to the number of tourists who visited Indonesia in September 2016 .

In line with the increasing target of inbound tourists, then the government in the region also aggressively develops the tourism village. The Minister of Village Development of Underdeveloped Regions, and Transmigration Eko Putro Sanjoyo said that the development of tourism village can be a step to promote the village community economy in Indonesia. If a village is developed, it will be able to develop the potential of the village, including tourism, as a superior product of the village.

The tourism village is now a favorite modern tourism activities. Historical potential and education for some people is much more meaningful to fill the holiday time than the frenetic urban attractions. Each village has its own characteristics. This is different from the modern tourist attraction that requires make-up to be called worthy, tourist villages precisely sought because of the natural situation that tourists encountered. One of the tourism villages close to the capital city of Jakarta is Kampur Tajur Tourism Village (KTTV). This village is located at the foot of Mount Burangrang Purwakarta city of West Java. The village has natural attractions, cultural tourism, and artificial tourism. Nature tourism such as Burangrang mountain scenery, eco-tourism based on local wisdom, agriculture, Ciherang river, Kahuripan Waterfall. Cultural tourism is traditional culinary such as wajik, snack made of sticky rice with brown sugar covered by banana leaves. Artificial tourism includes 143 homestay that are built uniform (each house consists of 2 bedrooms).

The uniqueness of this village that the formal leader isn't so strong to involve in developing KTTV but the tourism activities have been running well without any frictions.

The previous study found that social capital contributes to sustainable development of the village [1] and so the local economic growth [2]. And according to Baum et al. (2000:255) participation is an aspect that is able to describe social capital in the community [3].

According to the background above, the study will identify community participation as an aspect of social capital at Kampung Tajur Tourism Village in Purwakarta. In this case the question of the study was 'How is the community participation at Kampung Tajur Tourism Village in Purwakarta?' 


\section{LITERATURE REVIEW}

Social capital is able to contribute to increased resilience. This is because social capital can lead to the emergence of a collective response [4]. The concept of social capital in the development of tourism business in Guangxi, China shows that social capital contributes to people's ability to develop tourism business, especially in rural areas [5].

Community participation is an important aspect in the sustainability of a tourist destination [6] \& [7]. More specifically, women's participation can increase incomes and make them act as decision makers [8] (Sita, K. \& Herawati, E., 2017). Participation is an interesting aspect to be analyzed [9]. Community participation varies depending on the type of business [10] (Viren, 2015). On the one hand the participation of rural tourism communities tends to be weak in developing countries [6].

Tourism is a rising sector and has a positive impact on the economic and business aspects [11], [12], [13], [14], \& [15]. This is evidenced by the opening of many employment opportunities in the field of tourism [16]. Ecotourism sector can help to improve the family economy in Batusuhunan Sukabumi [17]. Thus the tourism sector provides a dominant influence on the economic growth of an area and provides prosperity to local communities [18]. The community in Cibuntu tourism village is an example of tourism village that is able to develop its income by doing tourism activities [19]. In addition, many popular tourist destinations are visiting agro tourism, enjoying natural scenery, visiting historic relics, as well as artificial tourism such as zoos or culinary tours [20].

Reaching Kampung Tajur isn't easy. One of the ways to get there from Jakarta is by getting on the train. It takes around one and a half hour until arriving at Purwakarta railway station. After that we have to reach there for around an hour by driving car. There isn't any public transportation to reach Kampung Tajur. Based on this situation, It's interesting to understand "why is Kampung Tajur Tourism Village able to attract the attention of the tourists?" Research framework can be seen in Figure 1.

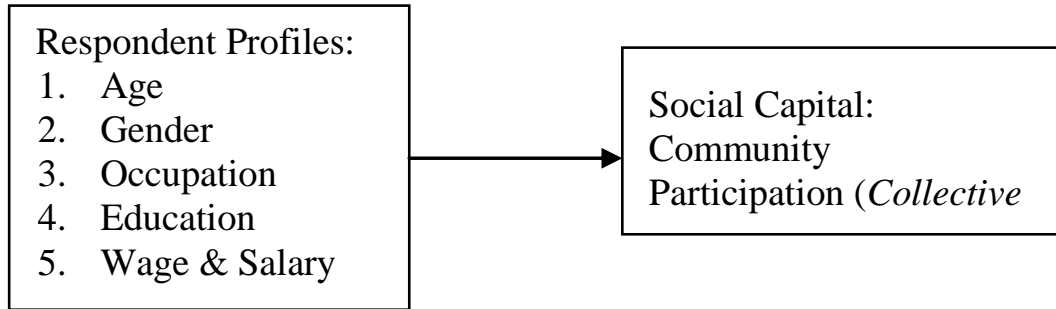

FIG 1. RESEARCH FRAMEWORK

\section{METHODS}

Research method is quantitative method, with descriptive approach because this research aim to get complete picture about participation owned by DWKT which become object of research. The time used is cross-sectional. The technique of collecting data using questionnaires consist of two parts. The first part, regarding the profile of respondents, while the second part about social capital variables. The unit of analysis of this research is about 79 families in DWKT. In this study the sampling by Accidental Sampling, ie the process of sampling is done by chance without a certain consideration.

The research will be conducted at Kampung Tajur Village (DWKT), Pasanggarahan, Purwakarta. The time required for the implementation of the study for 6 (six) months is effective from October 2017 to February 2018.

Variables are characteristics of different people, objects, or events in the values encountered in the person, object, or event. The variable in this study is social capital.

To obtain data on collective action, respondents are asked to vote for available answers or fill in if appropriate answers are not in the options. Respondent profile data, Variable, Sub-variable and measurement of this research can be explained in table 1 . 
TABLE 1. RESPONDENT PROFILE, VARIABLE AND SUB VARIABLE, MEASUREMENTS SCALE

\begin{tabular}{lll}
\hline Data/Variable & Sub-data/ Sub Variabel & Measurement Scale \\
\hline Data: & Sub-data: & \\
Respondents profiles & 1. Age & Interval \\
& 2. Gender & Nominal \\
& 3. Occupation & Nominal \\
& 4. Formal education & Nominal \\
Variable: & 5. Income & Interval \\
Social Capital & Sub-variabel: & \\
\hline
\end{tabular}

Data analysis performed include descriptive analysis, Pearson correlation analysis, with the help of softwareSPSS 20 for Windows [21], with the following explanation:

Descriptive statistical analysis is the activity of collecting and summarizing the data, as well as the presentation of the summary result, that is looking for central tendency, measuring sub variable which is most appropriate and at least according to the expectation of the respondent. By using the formula of measure of location obtained by equation: $\mathrm{L}=[\mathrm{k}(\mathrm{n}+1)] / \mathrm{n}$. Where $\mathrm{k}=$ the size of the location to ......; $\mathrm{n}=$ number of data or Likert measuring scale. Once calculated, the interval score is obtained as shown in Table 2.

\begin{tabular}{ll}
\multicolumn{2}{l}{ TABLE 2 INTERVAL SCORE AND EVALUATION } \\
\hline Interval Score & Evaluation \\
\hline $1,00-1,20$ & Strongly disagree \\
$>1,20-2,40$ & Disagree \\
$>2,40-3,60$ & Normal \\
$>3,60-4,80$ & Agree \\
$>4,80-5,00$ & Strongly agree \\
\hline
\end{tabular}

Pearson correlation analysis is completed to know the strength of relationship between variables [21]. The correlation value range is shown in Figure 2.

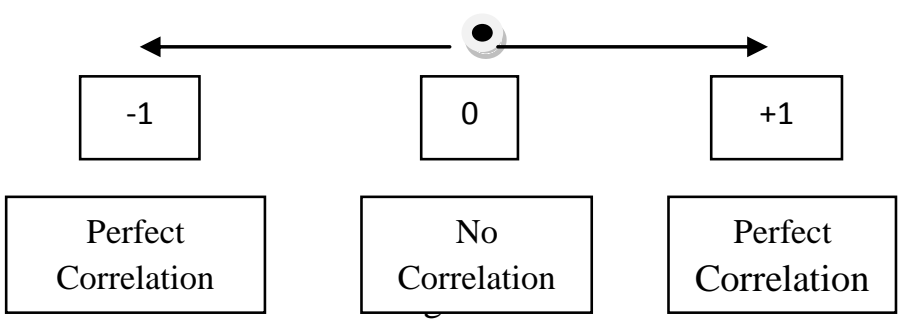

FIG 2. PEARSON CORRELATION VALUE

A correlation number above 0.5 indicates a strong correlation; while below 0.5 correlation is weak. The (-) sign at the output indicates the direction of the opposite relationship, whereas the (+) sign denotes the direction of the same relationship.

\section{RESULT AND DISCUSSION}

The Research of 'Identification of Community Participation as one of Social Capital at Kampung Tajur Tourism Village in Purwakarta', highlights the community 'Participation' in Kampung Tajur Pasanggarahan village. Based on the data of respondents it can be explained that from a total of 38 respondents, the majority of respondents' age is forty years up to sixty years. Most the respondents in the village is the people who has the religious orientation in their life. The majority of gender respondents gender is female (thirty people).

There are thirty respondents who have the occupation as a farmer. It's interesting that the female who are the housewife are also working as farmers as well. Generally, they work on other people's fields although some work on their own farms. Another interesting thing is most of the male who 
work as farmers, they also work as construction workers. And in general, respondents feel that they have fulfilled their life by working in kampung Tajur so they do not have the desire to find a job outside the village. This indicates that Kampung Tajur has a lot of potential work that can be worked on. The cultivated farms are rice, corn, cabbage, onion, chives, and banana. Some respondents also work as palm sugar farmers, grass cut workers for goat food, caretaker tomb, and grocer. Based on the results of data collection, thirty-eight respondents obtained thirty-two people only elementary school (SD), and even then the majority did not pass. Especially for many female respondents only four respondents who graduated from elementary school while twenty-six female respondents did not pass primary school (only up to the third or fourth grade).

Related to the participation of respondents in the activities in the village of Kampung Tajur in Pasanggarahan village, thirty-three respondents claimed to participate in activities in the Kampung Tajur Pasanggrahan village.

TABLE 3. FREQUENCY OF RESPONDENTS' PROFILES DAN PARTICIPATION (Primary data, December 2017)

\begin{tabular}{|c|c|}
\hline Age: & Frequency \\
\hline$>20$ years old & 1 \\
\hline $20-<40$ years old & 12 \\
\hline $40-<60$ years old & 18 \\
\hline$\geq 60$ years old & 7 \\
\hline \multicolumn{2}{|l|}{ Gender: } \\
\hline Male & 8 \\
\hline Female & 30 \\
\hline \multicolumn{2}{|l|}{ Occupation: } \\
\hline Unemployment & 1 \\
\hline Farmers & 30 \\
\hline Vendors & 2 \\
\hline Employee & 5 \\
\hline \multicolumn{2}{|l|}{ Education: } \\
\hline Elementary School & 32 \\
\hline Junior High School & 6 \\
\hline \multicolumn{2}{|l|}{ Income: } \\
\hline$<$ IDR500.000 per month & 3 \\
\hline IDR500.000 - IDR1.000.000 per month & 30 \\
\hline IDR1.000.000 - 2.000.000 per month & 3 \\
\hline IDR 2.000.000 - IDR3.000.000 per month & 2 \\
\hline \multicolumn{2}{|c|}{ Participation in formal meeting in the village: } \\
\hline Yes & 33 \\
\hline No & 5 \\
\hline \multicolumn{2}{|l|}{ Community Meeting: } \\
\hline $0-11$ times per month & 10 \\
\hline$>12$ times per month & 28 \\
\hline \multicolumn{2}{|l|}{ Tourism Participation: } \\
\hline Homestay & 31 \\
\hline Others & 7 \\
\hline \multicolumn{2}{|l|}{ Religious Meeting: } \\
\hline Yes & 38 \\
\hline No & 0 \\
\hline \multicolumn{2}{|l|}{ Community Activity: } \\
\hline None & 1 \\
\hline Quite active & 1 \\
\hline Active & 21 \\
\hline Very active & 15 \\
\hline
\end{tabular}


The form of participation of respondents in the village of Kampung Tajur Pasanggrahan village includes following religious activities (pengajian). The recitation activity is followed by respondents three times in a week. It's on Sunday, Monday and Saturday. The participation of respondents' activities is also in the form of attending religious commemoration, such as the Prophet's Maulid.

Some respondents also participated in tourism activities in the village of Tajur village pasanggrahan. Participation form is as tourism activist like Mr. Solihin and Mrs. Rini. While the respondents who helped the availability of consumption for the guests (if there are guests' entourages) are the mother of grandchildren. While Ms. Nining is one of the homestay owners. The homestay owners who were respondents in Kampung Tajur are thirty one respondents. In general, the respondents are active but one respondent isn't participate actively in Kampung Tajur.

Based on the mean descriptive analysis of the respondent's profile on the participation of respondents in the activities of the village of Tajur Pasanggarahan village can be explained as follows: The social capital of the Kampur Tajur Village Village which includes the general community participation is shown in Figure 3.

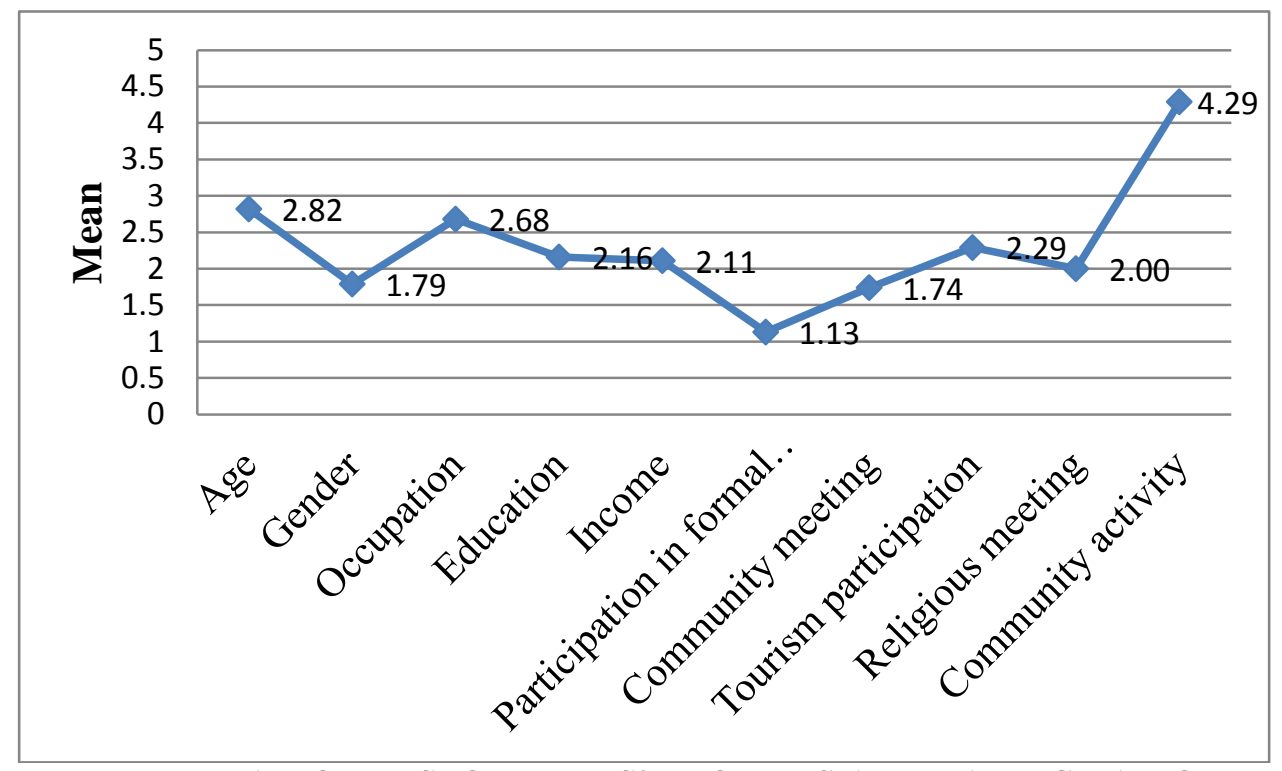

FIG 3. MEAN OF RESPONDENTS' PROFILES AND PARTICIPATION

(Primary data, December 2017)

Based on the data of the mean calculation, the average respondents answered not participate in formal meeting, especially for village development meetings that is held by the village head. They also revealed that they did not attend the village community meetings. However, for community participation in tourism activities such as providing homestay and consumption for guests who visit the village of Kampung Tajur, the involvement is higher although it has not indicated that the respondents actually participated in the tourism activity actively. Especially in terms of village activity is still very low. However, in the case of recitation activity all respondents stated that they were actively involved (mean 4.29). Mr Solihin, a tourism activist (44 years), "I am currently never present at village meetings except religious events or recitals."

Pearson correlation analysis to see the relationship between age and partipation of Kampung Tajur Village Village community that includes community participation; the relationship between gender and participation of Kampung Tajur Tourism Village; the relationship between occupation and participation of Kampung Tajur Tourism Village; the relationship between education and participation of Kampung Tajur Tourism Village; and the relationship between income and participation of Kampung Tajur Tourism Village can be seen in figure 4 .

Based on the data contained in figure 4 it is described that gender and occupation have a strong correlation in shaping social capital in terms of community participation. This means that female's groups in Kampung Tajur Tourism Village who have farming jobs have a strong correlation in social capital, especially in terms of participation in activities in Kampung Tajur Tourism Village. On the 
other hand, age, education and income factors do not have a strong correlation to the community participation.

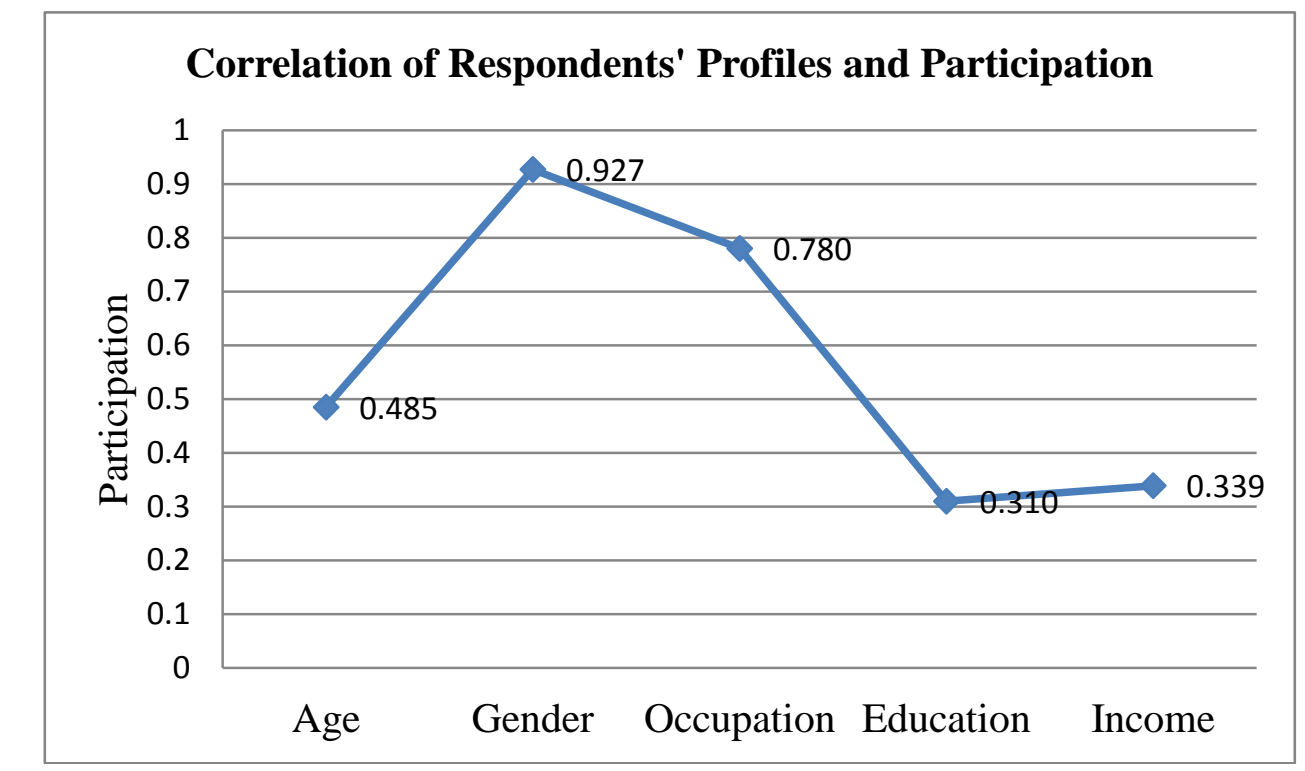

FIG 4. CORRELATION OF RESPONDENTS' PROFILES AND PARTICIPATION

(Primary data, December 2017)

\section{CONCLUSION}

Social capital of Kampung Tajur Village Village community that includes the participation of the community especially for activeness in pengajian activities in the village including strong. The group of female respondents who have jobs as farmers (other than as housewives) have a strong correlation and even tend to be very strong in shaping social capital especially related to community participation. Based on interviews with respondents obtained information that the more senior the public participation of activities in the village of Tajur higher, especially in pengajian activities. On the other hand, the level of education and income has no strong relation to the formation of social capital, especially related to the participation of the people in the village of Tajur tourism village in Pasanggrahan village, Purwakarta regency, West Java.

\section{RECOMMENDATION}

Coordination and cooperation between village officials (village heads) and tourism drivers and villagers must be improved and there is also the need for increasing knowledge and skills for the members of Kampung Tajur Tourism Village Community, especially for the female.

Acknowledgement. We appreciate to Sekolah Tinggi Pariwisata Trisakti that has facilitated us to do research in Tourism Village of Kampung Tajur in Purwakarta West Java, Indonesia.

\section{REFERENCES}

Amalia, M., \& Sumarti, T.,'Peluang Usaha serta Kerja Akibat Kehadiran Wisatawan pada Komunitas Tugu," .Sodality: Jurnal Sosiologi Pedesaan, 8(2), 109, (2014).

Arasli, H.; Baradarani, S.,"European Tourist Perspective on Destination Satisfaction in Jordan's Industries," Procedia: Social and Behavioral Sciences ,109, 1416-1425, (2014).

Alegre, J; Mateo, S; Pou, L.,"An Analysis of Households' Appraisal of Their Budget Constraints for Potential Participation in Tourism," Tourism Management Journal, 31, 45,(2017).

Dhalyana, D., \& Adiwibowo,S.,"Pengaruh Taman Wisata Alam Pangandaran terhadap Kondisi Sosial Ekonomi Masyarakat (Studi: Desa pangandaran, Kecamatan Pangandaran, Kabupaten Ciamis, propinsi Jawa Barat," Sodality:Jurnal Sosiologi Pedesaan, .7(3), 214, (2013).Grootaert,C., and Thierry Van Bastelaer,'Understanding and Measuring Social Capital:"A Synthesis of Finding and Recommendations 
from the Social Capital Initiative," Social Capital Initiative Working Paper no.24, The World Bank,1.(2001).

Eshliki, S.A.; Kaboudi,M.,"Community Perception of Tourism Impacts and Their Participation in Tourism Planning: A Case Study of Ramsar, Iran," Procedia: Social and Behavioral Sciences 36, 333, (2012).

Hijriati, E., \& Mardiana, R.,’Pengaruh Ekowisata Berbasis Masyarakat terhadap perubahan Kondisi Ekologi, Sosial, dan Ekonomi di Kampung Batusuhunan, Sukabumi," Sodality:Jurnal Sosiologi Pedesaan, 8(3), 167, (2014).

Ingkadijaya, R.; Damanik, J; Putra, H.S.A.; Nopirin,'Tourist Activities Contribution on Family Cohesion," in Radzi,S.M. et al(eds), Heritage, Culture, and Society: Research Agenda and Best Practice in the Hospitality \& Tourism Industry,": 345-350. London: Taylor \& Francis Group, (2016).

Liang, Z.X; Hui,T.K.,'Residents' Quality of Life and Attitudes Toward Tourism Development in China," Tourism Management, 57, 56, (2016).

Portes,A.,"Social Capital: Its Origins and Applications in Modern Sociology,"Annual Review Social 24,1-24 (1998).

Prabhakaran,S.;Nair,V.;Ramachandran,S.,"Community Participation in Rural Tourism: Towards a Conceptual Framework," Procedia: Social and Behavioral Sciences 144, 290, (2014)..

Pramanik, D.P.; Widyastuti, N.,'Rural tourism destination strategy through SWOT analysis in Cibuntu Village, Indonesia," Proceeding of ASEAN Tourism Research Forum 2017: 27-35, (2017). Sawatsky,T.,"The Influence of Social Capital on the Development of Nature Tourism: A Case Study from Bahia Magdalena, Mexico,"Simon Fraser University, 2008.

Rasoolimanesh,S.M., Masture, J., A. Ghafar,A., Rabeeh,B.,'Community participation in world heritage site conservation and tourism development,"Tourism Management, 58, 142-153, (2017).

Ruiu,M.L., Giovanna, S., Pier,P.R.," Developing adaptive responses to contextual changes for sustainable agricultural management: the role of social capital in the arborea district(Sardinia, Italy)," Journal of Rural Studies, 49, 162, (2017).

Santoso, S,."Panduan lengkap SPSS Versi 20: Edisi Revisi," Jakarta: Penerbit PT Elex Media Komputindo, hal.163-380, (2014).

Sariisik, M.; Turkay, O.; Akova, O.,"How to Manage Yacht Tourism in Turkey: A SWOT Analysis and Related Strategies,” Procedia: Social and behavioral Sciences 24, 1014-1025, (2011).

Sita, K. \& Herawati, E.,'Relasi Gender pada Pekerja Pemetikan The: Studi Kasus Pembagian Kerja dan Relasi Gender di Perkebunan The Gambung Jawa Barat," Sodality: Jurnal Sosiologi Pedesaan, Fakultas Ekologi Manusia Institut Pertanian Bogor, 5(1), 1, (2017).

Thammajinda,R.(2013). Community Participation and Social Capital in Tourism Planning and Management in a Thai Context. A Thesis of Doctor of Philosophy. New Zealand: Lincoln University, hal.19.

Viren, P.P.; Vogt, C.A.; Kline,C.; Rummel,A.M.; Tsao, J.,'Social Network Participation and Coverage by Tourism Industry Sector," Journal of Destination Marketing \& Management 4, 110, (2015).

Zhao, W., J.R. Brent, R., Charlotte, M.E.,'Social capital and tourism entrepreneurship," Annals of tourism research, 38(4), 1570, (2011). 